even genocide: ministers secretly agreed to "tilt" towards Iraq with regard to exports related to arms in December 1988, only eight months after the bombing of Kurdish villages with poison gas-part of a definitive attempt to eliminate Kurdish life and culture-had been in the news worldwide. Ministerial acknowledgment of this was limited to a concern with presentation and meant that the full facts were kept from the Commons and wider public.

In the 1990s the strategic tilt is in the reverse direction and Britain seeks warmer relations with Iran. What of the experiences of the Iranian refugees in my current caseload?

A 28 year old woman was strung up, whipped, and raped in front of her 4 year old son by officials seeking her husband. The boy was tortured in front of her: long cuts were made with razor blades. She fled in 1993.

A 47 year old Kurdish woman fled in 1991. Her husband, daughter, and son had been detained and tortured. She had been summoned to be told that her daughter and, later, son had been extrajudicially executed. When she protested her son's innocence, officials assured her that if they had made a mistake he would go to paradise.

A 29 year old medical student in her final year was accosted by a revolutionary guard outside the teaching hospital; after a verbal altercation he shot her classmate dead in front of her. No protest was possible, and the university authorities were pressurised to expel her. She hid in her parents' home for three months and fled in 1992.

A 37 year old man was tortured; this included mock executions and being burnt with a hot skewer. His 70 year old mother was allowed to visit only if she humiliated herself by stripping naked. $\mathrm{He}$ was moved from Evin to Gohadasht prison, where he heard firing squads every night. Young girls there were raped by guards before being shot or hanged. He fled in 1992, but his brother was arrested and may be under sentence of death to force him to return.

A 32 year old Kurd spent four years in prison under an extreme brutal regime. His job was to wash the bodies of executed prisoners; he estimates that he saw 10000 in this time. He fled in 1992.

Reports by Amnesty International confirm the systematic and institutionalised nature of these acts, affecting thousands of new victims every year. ${ }^{1}$ For how long will this continue to weigh so little with decision makers in the West?

DEREK SUMMERFIELD

Medical Foundation for the Care of Victims of Torture, London NW5 3EJ

1 Amnesty International. Annual report. London: Amnesty International, 1992:144-6.

\section{Salt and asthma}

EDrToR,-Alan J Knox has reviewed evidence suggesting a relation between a high salt intake and worsening of asthma in men ${ }^{1}$ and discussed two hypotheses to explain this-namely, Blaustein's hypothesis and the hypothesis that the deterioration in asthma is due to the fall in circulating catecholamine concentrations that occurs during salt loading. We and colleagues have published findings that may provide a much simpler explanation.

We have shown that a reduction in salt intake from $200 \mathrm{mmol} /$ day to $50 \mathrm{mmol} /$ day over two weeks causes up regulation of $\beta_{2}$ adrenoceptors on lymphocytes (as well as concomitant down regulation of $\alpha_{2}$ adrenergic receptors on platelets). ${ }^{23}$ These changes in the densities of adrenoceptors are reversible: a subsequent high salt diet $(200 \mathrm{mmol}$ day over two weeks) causes a decrease in $B_{2}$ adrenoceptors and an increase in $\alpha_{2}$ adrenoceptors. Receptor affinities remain unchanged. These changes in adrenoceptors are more pronounced in subjects whose blood pressure falls when they have a low salt intake (that is, those who are sensitive to salt). In a subsequent study we showed that subjects who are sensitive to salt have a decreased expression of $\beta_{2}$ adrenoceptors on cultured fibroblasts, which presumably is determined genetically. ${ }^{4}$

If our findings also apply to airway smooth muscle cells a high salt intake would lead to reduced bronchodilatation mediated by $B_{2}$ receptors. A body of literature exists in favour of the so called $B$ adrenergic theory of asthma, which postulates disturbed $B_{2}$ adrenergic function as a cause of asthma. ${ }^{5}$ It would be interesting to measure $\beta_{2}$ adrenoceptors on cultured fibroblasts of patients with asthma as this might give evidence for a possible genetic background. It would also be interesting to test our findings regarding adrenoceptors on lymphocytes in patients with asthma during high and low salt diets.

PETER KOTANKO FALKO SKRABAI

Department of Internal Medicine,

Krankenhaus Barmherzige Brüder (Marschallgasse),

A-8020 Graz,

Austria

1 Knox AJ. Salt and asthma. BMf 1993;307:1159-60. (6 November.)

2 Skrabal F, Kotanko P, Meister B, Doll P, Gruber G. Upregulation of $\alpha_{2}$ adrenoceptors and downregulation of $B_{2}$ adrenoceptors by high salt diet in normotensives: enhanced upregulation of "operative $\left(\alpha_{2} / \beta_{2}\right)$ adrenoceptor ratio" predicts salt lation of "operative $\left(\alpha_{2} / B_{2}\right)$ adrenoceptor ratio"

3 Skrabal F, Kotanko $P$, Luft FC. Minireview: inverse regulation of $\alpha_{2}$ and $B_{2}$ adrenoceptors in salt sensitive hypertensionhypothesis. Life Sci 1989;45:2061-76.

4 Kotanko P, Hoglinger O, Skrabal F. $B_{2}$ Adrenoceptor density in fibroblast culture correlates with human $\mathrm{NaCl}$ sensitivity. $A m$ f Physiol (Cell Physiol) 1992;263:C623-7.

5 Krzanowski JJ, Polson JB, Goldman AL, Ebel TA, Szentivanyi A. Reduced adenosine 3',5'-cyclic monophosphate levels in patients with reversible obstructive airways disease. Clin Exp Pharmacol Physiol 1979;6:111-5.

\section{Incentives in the internal market}

EDrToR,-Neil Goodwin is right that success in the internal market should be reinforced. ${ }^{1}$ But the incentives must be to the trust as a whole and not to individual people. A successful trust can reward outstanding groups or departments by supporting and developing their budgets. That way the morale of all who work in the department is raised. Individual performance related pay is a sick jokeas much for managers as for clinicians-and is divisive and destructive of team loyalty.

London NW3 2PH

REBAN

1 Goodwin N. Making the internal market work. $B M F$ 1994;308: 206. (15 January.)

\section{Use of a telephone advice line in an $A$ and $E$ department}

EDrTor,-Conor V Egleston and colleagues report the use of a telephone advice line in an accident and emergency department. ${ }^{1}$ We acknowledge that there is public demand for medical advice over the telephone, but the authors report that inappropriate information was given on two occasions during their study, one occasion being after accidental poisoning.

The accident and emergency department at Leeds General Infirmary has developed strong links with the National Poisons Information Service, which is a valuable source of information. The service provides a 24 hour telephone inquiry answering service to members of the medical profession and will give specialised advice about the management of poisoned patients. We recom- mend that a poisons centre should be contacted whenever information about a specific poisoning is required. (The numbers of all the poisons centres are listed in the inside front cover of the British National Formulary.) The use of this service would reduce the risk of inappropriate advice or treatment being given to patients, which could jeopardise an otherwise worthwhile scheme.

Leeds Poisons Information Service,

LYNNE HODGSON

Pharmacy Department,

Leeds General Infimt,

Leeds LS1 3EX

Department of Accident and Emergency,

Leeds General Infirmary,

Leeds LS1 3EX

1 Egleston CV, Kelly HC, Cope AR. Use of a telephone advice line in an accident and emergency department. BMF 1994;308:31. (1 January.)

\section{Bed sharing and sudden infant death syndrome}

EDITOR,-We agree with $\mathrm{R}$ Scragg and colleagues that the role of bed sharing in the sudden infant death syndrome needs further clarification. ${ }^{1}$ Our view is based on our experience in South Australia, which has a population of about 1.46 million and where virtually all postmortem examinations in cases of the syndrome are carried out at Adelaide Children's Hospital.

Since a large publicity campaign in South Australia in 1991 regarding the increased risk of the sudden infant death syndrome associated with the prone sleeping position the incidence of infants dying of the syndrome has fallen considerably (table). At the same time there has been a rise not only in relative terms but also in the absolute numbers of infants whose death was attributed to the syndrome and who were found dead in bed with one or both parents.

In July 1988 one of us (SMB) conducted a postal survey of the usual sleeping environment of 220 consecutively registered infants in South Australia when the infants had reached the age of 12 weeks; 197 replies were obtained. The results were: bassinet 89 infants; cot 59 ; crib 39 ; pram 4 ; parent's bed $3(1.5 \%)$; capsule 1 ; other unspecified 2 . The survey indicated that even at that time infants sharing the parental bed were overrepresented in the population dying of the sudden infant death syndrome.

Despite Scragg and colleagues' conclusion our own experience suggests that consumption of alcohol by the parent sleeping with the infant on the night of death may be a factor and is worthy of further study.

Clearly, more multi-centre studies are needed to determine with certainty whether bed sharing by

Number of cases of sudden infant death syndrome (SIDS) and number in which infant shared bed with parent in South Australia, 1983-93

\begin{tabular}{lcl}
\hline & No of cases of SIDS & $\begin{array}{c}\text { No in which infant } \\
\text { shared bed }\end{array}$ \\
\hline 1983 & 31 & 2 \\
1984 & 40 & 4 \\
1985 & 42 & 4 \\
1986 & 40 & 3 \\
1987 & 52 & 1 \\
1988 & 31 & 3 \\
1989 & 35 & $23(7 \cdot 5 \%)$ \\
1990 & 35 & 6 \\
\hline Total & 306 & 8 \\
\hline 1991 & 23 & 7 \\
1992 & 25 & $21(32 \cdot 3 \%)$ \\
1993 & 17 & \\
\hline Total & 65 &
\end{tabular}

